\title{
Merkels udenrigspolitik
}

Jan Bo Hansen

De nyligt afholdte topmøder har skabt forudsætningerne for en effektivisering af beslutningsgangen i EU og øget Angela Merkels popularitet i Tyskland. Men de egentlige spørgsmål, EU's manglende $ø$ konomiske dynamik og politiske handlekraft er lige langt fra deres løsning

EU-topmødet blev en succes for det tyske formandskab og den tyske kansler, Angela Merkel. Så meget kan siges uden at overvurdere indholdet af de trufne aftaler. Det er naturligvis rigtigt, som det er blevet fremhævet, at de spørgsmål, der blev diskuteret, på ingen måde er de centrale, men man kan argumentere for, at de er en forudsætning for kommende beslutninger.

At isolere Polen, også fra de østeuropæiske stater, var en del af spillet, og man må sige, at denne del lykkedes, ganske vist med entusiastisk medvirken fra polakkerne selv. Den kraftigste kritik af den polske forhandlingstaktik er da også kommet fra polske kredse, venner af den polske regering, der ikke mente, at polakkerne havde isoleret sig tilstrækkeligt. Der kunne være gjort meget mere i den henseende.
På samme måde var udfaldet af G8-mødet i Heiligendamm en succes for Angela Merkel. Måske vil mødet ikke få den store betydning for klodens klima, måske var den tilsyneladende amerikanske indrømmelse kun en kulisse, der i sidste øjeblik blev skubbet ind på scenen. Men resultatet har fremmet tiltroen til den tyske kansler, til hendes evne til at skabe kompromiser og fremme samarbejdet mellem Europa og USA.

Det var evner, hun allerede viste i begyndelsen af sin regeringstid, under EU-topmødet i december 2005, hvor hun mæglede i stridighederne (især mellem Storbritannien og Frankrig) om EU-budgettet. Disse evner er nu endnu en gang blevet dokumenteret.

Dermed kan man sige, at udenrigspolitikken har fremmet den tyske selvbevidsthed, som der har væ- 


\section{JAN BO HANSEN}

ret en del tale om på det sidste, ofte i forbindelse med fodboldverdensmesterskabet.

\section{Ny selvbevidsthed}

Den tyske selvbevidsthed var der nu før dette mesterskab. Hvis man kan regne med Institut für Demoskopie i Allensbach, er den opbygget over de seneste tre år. I 2004 faldt selvbevidstheden til et lavpunkt, men derefter begyndte den at stige i et rask tempo, uden at nogen kunne sige hvorfor. Det skete ganske uafhængigt af konjunkturerne eller foregribende om dem.

Det gode resultat ved fodboldmesterskabet, det tyske mandskabs overraskende fine spil, gjorde også sit, men af betydning var især afviklingen af mesterskabet, den positive stemning, som stod i en så skærende kontrast til de blodige dystopier om vold, racisme, død og ødelæggelse, som tysk og udenlandsk presse havde spredt om sig i månederne forinden.

Det økonomiske opsving har gjort resten, den overraskende høje vækst, den stigende beskæftigelse, den pludselige forbedring af statens finanser, der gør, at Forbundsrepublikken for første gang siden 2001 er i stand til at overholde Stabilitetspagtens krav. Der er ganske vist tale om konjunkturelt bestemte forandringer, som ikke vil holde evigt, måske ikke engang særligt længe.

Men hvad den end skyldes, er stemningen ægte nok, de mange spådomme om republikkens nedgang er glemt og erstattet af en wirsind-wieder-wer-stemning, som midt i det gladeste Wirtschaftswunder.

Den nærer sig af den økonomiske udvikling, den forstærkes af Angela Merkels succes på det udenrigspolitiske område. På det indenrigspolitiske er der imidlertid snarere tale om stagnation, permanente gnidninger mellem koalitionspartnerne og kompromiser på den absolut laveste fællesnævner.

Koalitionsregeringen synes at være nået til vejs ende med sine politiske projekter, de to parter forbereder allerede nu næste valgkamp, der ligger to år ude i fremtiden, og forsøger at trække andre over i den kommende regering, som kan være sort-gul (CDU/CSU og FDP), rødgrøn (SPD og De Grønne), sort-gulgrøn, rød-gul-grøn... Ingen ønsker en forlængelse af den nuværende 'store koalition', og alligevel er den ikke usandsynlig. Men i alt dette spiller udenrigspolitikken en underordnet rolle.

Den ny regering fremhævede, som enhver anden regering ville have gjort det ved sin tiltrædelse, kontinuiteten i sin udenrigspolitik. Koalitionsaftalen mellem CDU/CSU og SPD bekendte sig til kontinuiteten og til alle de kendte værdier, forgængerregeringen også bekendte sig til. Personsammensætningen bekræftede denne kontinuitet. Udenrigsminister blev en af Gerhard 
Schröders nærmeste medarbejdere, Frank-Walter Steinmeier, der også havde spillet en væsentlig rolle i udformningen af udenrigspolitikken sammen med Joschka Fischer. Statssekretær Reinhard Silberberg, der under Schröder havde været leder af udenrigsministeriets afdeling for europapolitik, blev Angela Merkels sherpa under EU-formandskabet.

På enkelte områder er der foretaget justeringer. I koalitionsaftalen fra 2005 fremhævede CDU/CSU og SPD naturligt FN's betydning og også Tysklands vilje til at "overtage et større ansvar med overtagelsen af en permanent plads i Sikkerhedsrådet" - et krav, forgængerregeringen havde sat højt på sin dagsorden.

Men i realiteten har regeringen trukket sig tilbage fra kravet om en tysk plads i FN's sikkerhedsråd. Man støtter stadig kravet om en EUplads, der ganske vist ikke er meget mere realistisk end kravet om et tysk. Men det vækker ikke helt så store lidenskaber hos de øvrige europæiske stater. Det skal vi nok sætte en stopper for, tænker de i Foreign Office og på Quai d'Orsay. Og ingen tvivl om det.

\section{Tysk formandskab}

Men koalitionsaftalen begyndte ikke uden grund med EU og det tyske formandskab for EU og G-8 . Det var den væsentligste udfordring for regeringen. Det var klart, at de øvrige regeringer så hen over hovedet på de øvrige formandskaber i forventningen om, at den tyske regering ville være tvunget til at gøre et behjertet forsøg på at få EU-samarbejdet ud af den blindgyde, hvor den havde befundet sig, ikke kun siden afstemningerne i Frankrig og Holland, men ret beset siden Nice-traktaten.

De sidste måneder af året 2006 blev brugt til at neddæmpe forventningerne. Det tyske udenrigsministerium udsendte en strøm af pessimistiske erklæringer, og som Angela Merkel nu er, underspillede hun fra begyndelsen mulighederne og dæmpede forventningerne: Det så ikke let ud, og man kunne ikke forvente noget.

Forestillingen er den, at Tyskland indtager en formidlende position mellem Storbritannien, der ønsker udvidelse, men ikke nogen uddybelse af integrationen, og Frankrig, der har det omvendt. Denne position, naturligvis i kombination med Tysklands størrelse, har altid været fremhævet son en forudsætning for Tysklands centrale rolle.

Mens ingen ville forvente, at Finland ville kaste sig ind i arbejdet for at bryde dødvandet, ville man bestemt forvente, at den tyske regering gjorde det. Alt andet, uanset udfaldet, ville være et nederlag.

Efter nogen tøven besluttede Angela Merkel sig for at søge at bevare de dele af forfatningstraktaten, der var af størst betydning, og kaste resten ud som ballast. Det kom igen- 
nem. Ganske vist skal det først bringes til udførelse med ti års forsinkelse som ønsket af polakkerne, men resultatet af EU-topmødet kunne demonstrere, at der er grænser for denne holdning, grænser for, hvor langt man kan udvide og hvor meget man kan uddybe samarbejdet på samme tid.

Hvilke følger der opstår af disse forhandlinger, skal først vise sig, men det er svært at tro, at hele forløbet slet ikke får nogle følger for den tyske EU-politik. De tider, hvor selve EU's eksistens var tilstrækkelig til at stemme sindene mildt i den tyske ledelse, er nok forbi med den generation, der rev grænsepæle ned og forkyndte en ny tidsalder, der ikke kendte nationer, men kun europæere. Den nuværende generation af ledere vil i højere grad afveje de håndgribelige fordele og ulemper.

\section{Nye medlemmer}

Hvad udvidelsen angår, er det en given sag, at staterne på Vestbalkan optages med vedtagelsen af Thessaloniki-erklæringen juni 2003, mens tidspunktet ikke er givet. Det kræver ingen særlige spådomsevner at sige, at det bliver senere for Serbiens vedkommende end for de øvrige, men at man skulle standse processen fuldstændig, er det vanskeligt at forestille sig. Så længe der er hvide pletter på Balkankortet, vil der også løbe en optagelsesproces.

Det afgørende problem er natur- ligvis Tyrkiet. Her har de to førende EU-medlemmer nu ledere (Merkel, Sarkozy), der er skeptiske over for det tyrkiske medlemskab, hvad der ikke har gjort situationen mere overskuelig efter det finske formandskab opgav at gøre mere ved sagen. Den 12. december 2006 blev det besluttet at udsætte forhandlingerne om 8 af de 35 kapitler. Cypernspørgsmålet må om ikke løses så dog bringes ud af det nuværende dødvande, før forhandlingerne kan komme videre.

Det er ikke til at overse, at EU har et væsentligt ansvar for den hårdknude, der er skabt, men det er også til at se, at mange EU-medlemmer finder denne hårdknude i deres interesse og ikke vil gøre noget for at løse den. Under det tyske formandskab er der ikke sket noget i den retning, men man må også sige, at tyrkerne heller ikke selv har gjort meget for at gøre det lettere.

Hvad Kosovo-spørgsmålet angår, er der naturligvis et problem i forholdet til Rusland, der har antydet modtræk, hvis Ahtisaari-planen om kontrolleret uafhængighed bliver ført ud i livet.

Men der er også et internt EUproblem, som kun er skjult på grund af Rusland. Spanien afviser energisk Ahtisaari-planen, fordi landet frygter, at det vil tjene som støtte til baskernes krav om selvstændighed. Også Italien, Slovenien og Grækenland er af forskellige grunde modstandere af Kosovos selvstændighed. Den ny franske præsident 
har foreslået en udsættelse på et halvt år.

Det er helt i overensstemmelse med den almindelige diplomatiske fremgangsmåde, der forestiller sig, at der så vil være sket et eller andet, som gør yderligere anstrengelser overflødige. Men dette halve år går jo også, og hvis Nicolas Sarkozy har svaret på, hvad der så skal ske, har han endnu ikke røbet det for offentligheden.

\section{Rusland}

Det var ventet, at forbundskansler Merkel i højere grad end forgængeren Gerhard Schröder ville tage hensyn til de østeuropæiske stater og i mindre grad til Rusland. Hun ville, formodede østeuropæerne, bryde med linjen fra Gerhard Schröder og Helmut Kohl, som helst havde set de baltiske og østeuropæiske stater uden for NATO for ikke at udfordre Rusland unødigt.

I substansen er forskellen imidlertid ikke stor. Merkel har ikke været indstillet på at afvikle olierørledningen gennem Østersøen. Hun har forsøgt at dæmpe de baltiske og polske bekymringer, men har ikke haft lyst til at give efter, når det drejer sig om sagens substans. Hun satte andre accenter end Gerhard Schröder under sit første besøg i Moskva ved at mødes med repræsentanter for oppositionen, ved at tage menneskerettighederne op.

Men sætningen: "I modsat fald, hr. præsident, ser vi os for fremtiden desværre ikke i stand til at aftage gas og olie fra deres side," faldt vistnok ikke.

Hvis den tyske holdning har været præget af en forstærket tyske selvbevidsthed, så har den russiske ledelse, formodentlig også den russiske befolkning, fra 2006 været præget af en forstærket russisk selvbevidsthed. På topmødet i Finland november 2006 sluttede den tyske regering sig til koret af Ruslands kritikere. Årsagerne var flere, men den væsentligste utvivlsomt, hvad man opfattede som en i tiltagende grad autoritær regeringsform.

Selv om man ikke vil gå så vidt som til at tro på Vladimir Putins umiddelbare ansvar for journalisters og kritikeres voldelige død, og selv om meget af kritikken er skudt over målet, er der alligevel en kerne i den, og i løbet af det sidste halvandet år er forholdet ganske langsomt blevet forværret.

Når Tyskland alligevel lægger vægt på det fortsat gode forhold til Rusland, skyldes det naturligvis de fælles interesser som sælgere og købere har, men det skyldes også mange andre historisk betingede forhold: Tyskland og Rusland har i mange år haft tætte forbindelser, af positiv og af negativ art. Mens Rusland for England og Frankrig er et fjernt land, og USA lægger vægt på at pleje en fjendtlig holdning, er forholdet for Tyskland væsentligt og betinget af umiddelbare interesser. Sådan 
har det været i mange år, og det vil næppe ændre sig, selv om regeringsformerne gør det.

\section{Øst- og Centraleuropa}

Angela Merkels overtagelse af regeringsmagten har ikke medført, at forholdet til de østeuropæiske stater er blevet bedre, som udviklingen under EU-topmødet også demonstrerede det. Forestillingen om denne mekanisme, at man kunne forbedre forholdet til Østeuropa ved at forværre forholdet til Rusland lå bag meget af den kritik, der blev Gerhard Schröder til del.

Forholdet til Polen var anspændt under Gerhard Schröders kanslerperiode, men kanslerskiftet har ikke bragt ændringer. Da det i 2005 viste sig, at præsidentkandidaten Donald Tusk havde en farfar, der som Volksdeutscher havde været indkaldt til værnemagten, var han færdig som præsidentkandidat. Kaczynskibrødrene kørte deres valgkamp på anti-tyske ressentiments og kørte den sikkert hjem.

I deres øjne var Gerhard Schröders tætte forhold til Vladimir Putin en fortsættelse af tidligere århundreders russisk-tyske entente på Polens bekostning, kulminerende med det nazistiske Tyskland og det stalinistiske Ruslands deling af landet. Henvisningerne til dette samarbejde blev som bekendt også strabadseret på det seneste EU-topmøde.

Angela Merkel forsøgte at dæmpe kritikken af olierørledningen ved at love polakkerne tilslutning til rørledningen, da hun mødte Kaczynskibrødrene den 2. december 2005.

Men selv om det ikke var tilstrækkeligt for de polske ledere, er det ikke let for Merkel at gå videre. At sløjfe ledningen, fordi den minder polakkerne om samarbejdet mellem Hitler og Stalin, kommer næppe på tale.

Men polakkerne er ikke lette at berolige, selvom de burde indse, at de næppe har nogen sandsynlighed for at få en mere positivt indstillet tysk regering end regeringen Merkel. Med Kaczynskis regnestykke under EU-forhandlingerne vil han også have fået de russiske diplomater til at spidse øren, for de 66 mio. indbyggere, som Polen ifølge Kaczynski ville have, hvis Tyskland ikke havde påbegyndt krigen i 1939, kan jo kun fremkomme, hvis Polen også tilskrives de landområder mod øst, som nu ligger i Litauen, Belarus og Ukraine. Hermed har han yderligere forværret forholdet til Rusland, hvis diplomater må have siddet med blyanten og lagt tal sammen i marginen for at finde ud af, hvilke områder, der kunne være tale om.

Det tyske forhold til de øvrige østog centraleuropæiske lande følger også gamle mønstre: Forholdet til Tjekkiet er et stykke fra det perfekte. Der er historiske årsager, fordrivelsen af sudetertyskerne, Benes-dekreterne, og ligesom i forholdet til Polen, erindringen om disse histori- 
ske fænomener gennem Zentrum gegen Vertreibungen, som forbundsregeringen i det mindste ikke vil tage afstand fra.

Og der er aktuelle problemer, i tilfældet EU den af præsidenten Vaclav Klaus propagerede linje, der kombinerer Margaret Thatcher med Kaczynski-brødrene. I militærpolitisk henseende har den tjekkiske regering ved at lade amerikanerne benytte tjekkisk territorium til opstilling af sit raketskjold stillet sig i modsætning til såvel EU som Rusland.

Forholdet til Slovakiet er derimod positivt. Sådan har det som regel været, og det kan hænge sammen med det dårlige forhold til Tjekkiet. Det sammen fænomen har man i tilfældet Ungarn, som Tyskland også har et positivt forhold til. Disse mekanismer er det ikke let for Angela Merkel at ændre, hvis hun da skulle have planer om at forsøge det.

\section{USA}

Der var store forventninger om et bedre forhold til USA, da Angela Merkel overtog regeringen. Især hvor det gælder forholdet til USA har hun den fordel, at hun ikke har været tvunget til at afslå deltagelse $\mathrm{i}$ Irakkrigen, hun er ubelastet i forholdet til George W. Bush. Da de to mødtes den 13. januar 2006 var det i en stemning af gensidig sympati, der fik Merkel til at tale om 'et nyt kapitel' i de to landes forhold. Men it t $a$ kes two to tango, og i praksis har det været vanskeligt at nå til enighed om konkrete spørgsmål.

I koalitionsaftalen fremhæves som altid fælles værdier - de koster ikke noget og alle kan lide dem: "Sammen med USA vil vi også i fremtiden arbejde for fred, demokrati og frihed i verden." Det kan man ikke indvende meget imod, men dels er disse begreber alle fortolkelige og fortolkes meget forskelligt forskellige steder i verden, dels kommer de tit i modstrid indbyrdes, dels i modstrid med de involverede interesser.

Til disse involverede interesser hører jo handelspolitikken. Næsten samtidig med at Angela Merkel fejrede sine triumfer som mægler i G-8 og EU, brød WTO-forhandlingerne, Doha-runden, sammen under almindelig uopmærksomhed. Det skete efter lang tids skranten, men man kan indvende, at de bryder sammen fra tid til anden, og mens vi nu taler om værdier og deslige er det værd at notere sig, at sammenbruddet ikke blev hidført af en eller anden despot med et konkurrerende værdisæt, men af europæerne og amerikanerne selv.

De samme grunde, som fik WTOforhandlingerne til at bryde sammen, ramte Transatlantic Free Trade Area, for nemheds skyld kaldet TAFTA. Der er ingen tvivl om, at TAFTA står højt på Angela Merkels private dagsorden: Liberal, som hun er nede på bunden, ville hun gerne se et stort frihandelsområde omfattende Europa og USA. 


\section{JAN BO HANSEN}

Problemet er imidlertid, at WTOforhandlingerne strandede netop på grund af amerikanernes og europæernes manglende evne og vilje til at skabe et kompromis på landbrugsområdet. At TAFTA i den ene eller anden form med den ene eller forkortelse, skulle lykkes, er derfor ikke særlig sandsynligt. Hvis TAFTA havde udsigt til succes, ville WTOforhandlingerne også have det, og det ville så være en mere naturlig ting at føre dem til en succesrig afslutning. Noget sådant er imidlertid ikke på dagsordenen.

Forholdet til USA lider utvivlsomt også under politiske modsætninger. Den tyske regering har næppe på noget tidspunkt delt forestillingerne om regimeskifte i Greater Middle East som vejen frem til en fredeligere verden. Angela Merkel er utvivlsomt nærmere ved dem, end Gerhard Schröder var det, men heller ikke hun kan vindes for deltagelse i krigen i Irak, for ikke at tale om en militær aktion i Iran. Det er der flere grunde til, en af dem utvivlsomt politisk selvopholdelsesdrift, men en anden og dybereliggende lige så utvivlsomt en grundlæggende skepsis over for projektet.

Amerikanerne har givet udtryk for deres misfornøjelse med, at tyskerne ikke vil udvide deres virksomhed til den sydlige del af Afghanistan, og uofficielt forhørt sig om muligheden for at udsende endnu fire battlegroups à 1000 mand. Men den tyske regering har en modvilje mod at ud- vide de militære missioner.

Tyskerne ser det jo meget anderledes end amerikanerne: Tyskland deltager i dag i en lang række aktioner i og uden for NATOs område, hvad der på ingen måde er nogen selvfølgelighed. Den tyske forfatning sætter en lang række begrænsninger, begrænsninger som på mange måder er overskredet. Tyskland befinder sig i dag i en fuldstændig anden situation end for tyve år siden, da Forfatningsdomstolen meget forsigtigt åbnede for tysk deltagelse i militære aktioner.

I Afghanistan overtog Tyskland ledelsen af ISAF, og der er nu udstationeret 3.000 tyske soldater. Man har kun det overordnede ansvar for de ni nordlige provinser, men har dog udvidet operationsradius til at omfatte hele Afghanistan. Til oktober skal mandatet fornys, og før det er sket, har tyskerne næppe lyst til at risikere flere menneskeliv, end de allerede $g ø r$.

\section{Andre engagementer}

Hertil kommer en række engagementer, som ikke alle er lige lette at sælge til den tyske befolkning. I Bosnien har tyskerne næsten 1.000 mand. Bosnien er ganske vist fredeligt, men udsigten til, at der kan skabes en levedygtig mekanisme ud af de tre dele, er ikke lys.

I Kosovo har tyskerne 2.900 mand, hvortil kommer politistyrker. Ganske uanset, om Kosovo bliver en 
selvstændig stat eller ej, kan tropperne forvente at blive der en rum tid endnu.

I Libanon er der lidt over 1.000 mand, og deres problemer skyldes for en stor del israelerne.

I Congo var der udsendt 760 mand i forbindelse med valgene, der nu igen er trukket tilbage. Når de blev udsendt, skyldtes det et pres fra Tysklands partnere, ikke nogen spontan bevægelse i Tyskland selv.

I Darfur er det til at forudse, at der skal udstationeres styrker om ikke andet så for at garantere sikkerheden for de FN-styrker, den Afrikanske Union har vedtaget at ville stille. Hvis de tyske tropper kommer derud, vil de utvivlsomt finde, at situationen er ikke så lidt mere kompliceret, end den hidtil er blevet fremstillet.

Der er i alt udstationeret 8.500 mand, hvad der måske ikke lyder af så meget. Men det er en kraftig ændring og udvidelse af den tyske udenrigspolitik, og den er ikke kommet i stand efter et folkeligt pres.

Tidsskriftet Internationale Politik spurgte et repræsentativt udsnit af befolkningen, om det troede, at de udsendte styrker bidrog til at øge Forbundsrepublikkens sikkerhed over for terroristiske angreb. Hertil svarede 84 procent nej, kun 13 procent ja.

De 84 procent ved måske ikke, hvad de taler om, men vælgere er de jo, og at udenrigspolitikken overhovedet intet hensyn skulle tage til be- folkningens overvældende flertal er jo et standpunkt, som det ikke er så let at forsvare i offentligheden.

Den tidligere forsvarsminister Peter Strucks påstand om, at Tysklands sikkerhed forsvares i Hindukush er i det mindste en fortolkning, og som alle fortolkninger kan den modsiges, og vil blive det i samme øjeblik, der kommer store omkostninger af menneskelig eller $\varnothing$ konomisk art. At Forbundsrepublikkens sikkerhed skulle afhænge af indførelsen af demokrati i stater, der aldrig tidligere har vist nogen interesse for denne vare, er jo en foruroligende påstand.

Ville republikkens sikkerhed være truet, hvis der ikke kommer demokrati - i vestlig forstand - i Afghanistan? Før eller siden vil denne påstand blive udfordret af oppositionen, der vil have et flertal i befolkningen på sin side. Merkel ved det, og af samme grund har hun ingen lyst til at udvide missionerne. Foreløbig henviser hun til den Hvidbog, forsvarsministeriet har bebudet om omlægningen af det tyske militær. Den skal komme sidst i 2007.

\section{Fremtiden}

Hvor fører alt det os hen? Hvad er det for problemer, Forbundsrepublikken står overfor? Angela Merkel har haft en heldig hånd ved de to topmøder, G-8's og EU's. Men på mange måder er disse løsninger kun forudsætningen for beslutninger af betydning for EU. 


\section{JAN BO HANSEN}

Afstemningsmodaliteterne kan være vigtige nok. Beslutningerne i EU tages ganske vist uden afstemning. Men bevidstheden om, at man kan komme til at tabe en afstemning, gør det naturligvis lettere at give efter. Et Polen, der vidste, at det ville være sikker på at samle et blokerende mindretal, uanset hvordan det opførte sig, ville utvivlsomt ikke være let at bide skeer med.

Men Lissabon-processen, som Angela Merkel har lagt så megen vægt på, er ikke kommet sin realisering nærmere. De bagved liggende problemer om manglende vækst, dynamik og innovation er ikke kommet nærmere en løsning, så lidt som de politiske problemer om manglende handlekraft i forhold til omverdenen. Alle alvorlige internationale kriser demonstrerer, at EU's fælles udenrigspolitik befinder sig meget langt fra sin realisering.

USA har hver gang været i stand til at spille dele af EU, det ny Europa, ud mod andre dele, det gamle Europa, som det senest er blevet de- monstreret i forbindelse med raketskjoldet, hvor den amerikanske regering indgår bilaterale aftaler med NATO- og EU-medlemsstater, uden at det øvrige Europa har nogen mulighed for at gøre sine indvendinger gældende.

Men det vigtigste spørgsmål er måske: Hvad er de tyske interesser? Under Helmut Kohl var der ingen (offentligt tilkendegivet) tvivl om, at Tysklands og EU's interesser faldt sammen. EU var i sig selv i tysk interesse, uanset hvad Tyskland konkret måtte få ud af det.

Under Gerhard Schröder kunne man måske snarere komme i tvivl. Hvordan ser forholdet ud nu i det udvidede EU, hvor mange problemer, der før udspillede sig mellem EU og andre stater eller grupper af stater, nu er blevet interne EU-problemer. Falder Tysklands og EU's interesser så stadig sammen?

Jan Bo Hansen er journalist ved Weekendavisen 